\title{
Nanoengineered Antibacterial Coatings and Materials: A Perspective
}

\author{
Krasimir Vasilev \\ School of Engineering, The University of South Australia, Mawson Lakes SA 5095, Australia; \\ krasimir.vasilev@unisa.edu.au
}

Received: 5 September 2019; Accepted: 9 October 2019; Published: 11 October 2019

\begin{abstract}
This feature article begins by outlining the problem of infection and its implication on healthcare. The initial introductory section is followed by a description of the four distinct classes of antibacterial coatings and materials, i.e., bacteria repealing, contact killing, releasing and responsive, that were developed over the years by our team and others. Specific examples of each individual class of antibacterial materials and a discussion on the pros and cons of each strategy are provided. The article contains a dedicated section focused on silver nanoparticle based coatings and materials, which have attracted tremendous interest from the scientific and medical communities. The article concludes with the author's view regarding the future of the field.
\end{abstract}

Keywords: infection; antibacterial; coatings; silver; nanomaterials; plasma deposition

\section{Introduction}

Infections have accompanied humans for millennia. Today, in the 21st century, despite being in the era of antibiotics, which began with the discovery of penicillin by Alexander Fleming in 1928, infections are still an important problem to human wellbeing. Antibiotics have saved countless lives and are considered by many as the greatest medical discovery of the 20th century. However, resistance emerged not long after the mass production and use of antibiotics had begun. Today, resistance is a significant issue since many bacterial species are no longer susceptible to commercially available antibiotics [1]. This requires the development of new compounds. However, the process is expensive, time consuming and associated with significant regulatory burdens. For these reasons, almost no new antibiotic compounds have been provided to the market in the last two decades.

Infections are a particularly difficult issue when associated with implantable medical devices [2]. For example, up to $2 \%$ of orthopaedic devices, $5 \%$ of trauma fixation devices and more that $20 \%$ of devices used for endoprosthetic reconstruction of large bone defects will become infected [3]. While infection rates of $1 \%-2 \%$ in the case of orthopaedic devices may not look too dramatic, infections are the reason for nearly $50 \%$ of all revisions that are required for this type of device [4]. Catheter related bacteraemia (CRB) is often defined as "a problem of epidemic proportion in the dialysis population" [5] The incidence of catheter related bacteraemia is in the range of 4-6 per 1000 patient-days in Australia, the US and other developed countries. A study conducted in Australia, and published in 2009, reported that 1163 patients out of 21,935 patients (5.1\%) who started dialysis therapy died of infections [6]. Among critically ill patients developing catheter-related bacteraemia, mortality rates are as high as $35 \%$, while survivors incurred increased hospital costs of at least $\$ 40,000$ and increased time spent in the ICU of 8 to 20 days [7].

The majority of medical device associated infections are caused by bacteria, although fungal and mixed infections have also gained recognition in recent years $[3,4,8]$. In a typical scenario, a medical device becomes contaminated by bacteria before or during the implantation procedure. In a proper clinical setting, this will be a relatively small number of bacteria. Once attached to the device surface, 
bacteria begins to proliferate and form colonies, express extra cellular products and a biofilm. With time, the biofilm matures and provides an effective protection for the bacteria from antibiotics and the patient's immune system. Bacteria in biofilm also undergo phenotypical changes, which makes them different to their planktonic counterparts and helps them to develop antibiotic resistance [1]. It is broadly acknowledged that bacteria in biofilm can resist 1000 times higher doses of antibiotics than planktonic bacteria. This presents significant challenges for the treatment of infected implantable medical devices since traditional antibiotic therapies can be ineffective [8-10]. In such situations, the only clinical option may be the removal and replacement of the device, which is a costly procedure that causes patient suffering and carries an even higher probability of infection. A further challenge is the population demographics receiving implantable medical devices, which in many cases is elderly people with reduced immune system strength and patients with supressed immune systems due to receiving chemotherapy (oncology patients) or treatments for other diseases.

\section{Antibacterial Coatings}

Since medical device associated infections often begin with the attachment of a few individual planktonic bacteria to the surface of the device, a concept that has gained tremendous attention from researchers, industry and healthcare professionals is the prevention of the initial bacterial attachment by applying antibacterial coatings. The breadth of research activities in this area is enormous and has been reviewed by us and many other authors [2,11-13]. In this invited feature article, the aim of the author is to summarise and place into perspective the research from our group on nanoengineered antibacterial surfaces and materials that was published over the last decade and is currently under development. The author is not rejecting or undermining the excellent work of many other researchers in the field, he is just adhering to the purpose of this feature paper.

Over the last decade, our team has developed four distinct classes of antibacterial materials and coatings. These classes of materials are schematically depicted in Figure 1. The first class (Figure 1a) of antibacterial coatings are those that bacteria simply do not like to attach to. This type of coating is typically based on hydrophilic polymers, such as polyethylene glycol (PEG), oxazolines, nitroxide radicals or chlorinated plasma polymers [14-18]. A specific section in this article will be attributed to oxazolines. The second class of coatings or modified material surfaces are those which are capable of killing bacteria upon contact (Figure 1b). An example of this coating is surface grafted quaternary ammonium compounds (QAC) $[19,20]$. Using a carefully designed number density gradient of QAC, our team was able to demonstrate that a surface concentration of $\mathrm{RNH}_{4}{ }^{+}$bonded nitrogen of $4.18 \%$ and surface potential of $+120.4 \mathrm{mV}$ is required to achieve the efficient killing of Escherichia coli [19]. While the strategies presented in Figure 1a,b are great approaches to stopping bacteria colonising on the surface of the device, they do not eliminate bacteria which may have infiltrated the site of implantation. This places an open wound at risk from opportunistic pathogens. To neutralise such pathogens, coatings or materials which release antibacterial agents were developed (Figure 1c). Many antibacterial compounds can be released by this strategy, including conventional antibiotics [21,22], nitric oxide [23-25], antibacterial polymers and peptides [26-28]. A special section of this article will be devoted to silver nanoparticles with an explanation of why such coatings are classified as releasing. The last category comprises of coatings and materials which release antibacterial on demand (Figure 1d), or only when photogenic bacteria have contaminated the device or its vicinity $[12,29,30]$. These 'intelligent' materials have many advantages compared to the other three classes of antibacterial coatings and will be discussed in a separate section. 


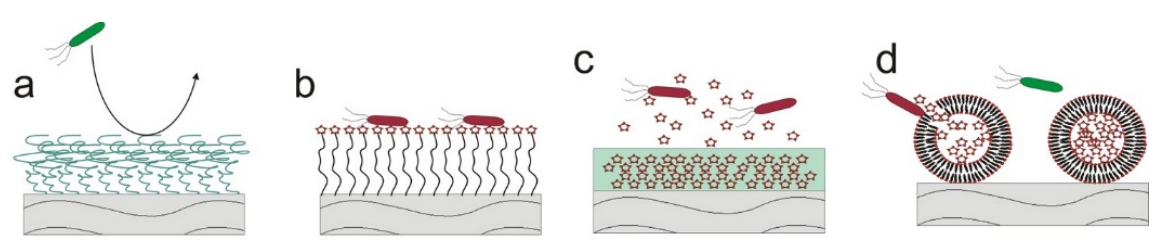

Figure 1. Classes of antibacterial coatings: (a) repelling bacterial attachment or biofilm development; (b) contact killing; (c) releasing of antibacterial agents; and (d) stimuli responsive release in the presence of bacteria.

\section{Plasma Deposition}

Many of our antibacterial coatings are facilitated by a method called plasma deposition [11,31]. Plasma coatings are deposited from the gaseous form of a selected precursor in which molecules are electrically excited to a plasma state. The nature of the technique offers unique versatility to deposit coatings of a wide range of functional groups, such as amine [32], carboxyl [33], hydroxyl [34], epoxy [35], oxazoline [36], chlorine [17], fluorine [37], siloxane [38], including from precursors that are not polymerizable by conventional means, such as ethanol [39]. The method is fast (seconds to minutes), can be completed in a single step and does not require the use of solvents as in the case of wet methods for surface modification [40,41]. Nanoscale coatings prepared by plasma deposition adhere well to almost any type of substrate material without the need for substrate pre-modification. We have also demonstrated that after a few nanometres of coating are deposited, the film growth becomes substrate independent [42-44]. This is a significant advantage since medical devices are made from all four classes of materials, i.e., polymers, metals, ceramics and composites. Using plasma deposition allows all of these materials to be coated by using the same process and without the need for process optimisation to suit a particular substrate material. In comparison, wet techniques for the preparation of thin films, such as Layer-by-Layer (LbL) or Self Assembled Monolayers (SAMs), are limited to the specific type of substrate material they require [45]. Moreover, plasma polymers can be deposited on substrates of complex shapes, such as porous materials or those having complex nanotopography, as well as micro and nanoparticles [22,24,37,46-50].

In the following, this article will provide a perspective on specific examples of the different classes of antibacterial surfaces depicted in Figure 1.

\section{Oxazoline Based Coatings That Inhibit Biofilm Growth}

A recently developed class of plasma polymers are those deposited from oxazoline precursors, such as 2-methyl-2-oxazoline and 2-ethyl-2-oxazoline [15,36,51-54]. Regardless of the precursor used, when appropriate conditions for deposition are used, the process results in coatings with properties that are very useful for biomedical applications. Uniquely, the plasma deposition process allows for the retention of intact oxazoline rings on the surface of the coatings, which would normally be lost if polymerisation was carried out by conventional ring opening. These rings are very reactive to carboxyl acid groups in a one-step, click type reaction without the need for any catalysts or intermediates. This special property allows for covalent binding of biomolecules, ligands and nanoparticles containing carboxyl acid groups, which provide platforms for developing diagnostic technologies and tools for interrogating biological phenomena occurring at the material interphase [55-58]. Oxazoline derived plasma polymer coatings were also demonstrated to efficiently modulate the immune responses exhibited by the reduction in secretion of pro-inflammatory cytokines and the composition of protein corona forming on the biomaterial surface $[15,56,59]$. In the context of this article, the most interesting property of oxazoline based plasma deposited coatings is the inhibition of biofilm formation $[14,15,53,60]$. An example is shown in Figure 2, which depicts four cell culture wells after incubation in a culture of $S$. epidermidis for $24 \mathrm{~h}$. A surface coated with an amine plasma polymer was used as a positive control. The images clearly show that bacteria were able to form a significant biofilm on the positive control surface (top right). However, when coatings based on oxazoline precursors were applied, the formation of biofilm was 
completely inhibited (bottom). Microscopy images confirmed these observations at the macroscopic level (shown in the right-hand side of the image). Our team is still interrogating the exact mechanisms by which coating deposited from oxazoline precursors inhibit bacterial growth. We expect to report on this phenomenon in the near future. In the meantime, this type of coating presents an appealing option for the modification of medical device surfaces, such as artificial heart valves, pacemakers and catheters. The fact that such low biofouling coatings can be prepared under atmospheric conditions using a plasma jet adds another dimension of interest [60].

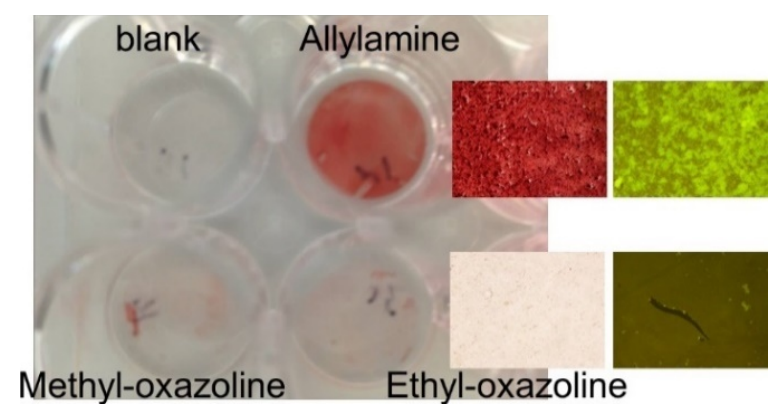

Figure 2. Growth of $S$. epidermidis for $24 \mathrm{~h}$ on glass coverslips coated with allylamine, 2-methyl-2-oxazoline and 2-ethyl-2-oxazoline. While biofilm readily forms on allylamine coated surfaces, a complete inhibition of biofilm growth is seen when the same type of substrate is coated with either 2-methyl-2-oxazoline or 2-ethyl-2-oxazoline. The microscopy images confirm the macroscopic observations.

\section{Contact Killing Surfaces}

Surfaces which are capable of killing bacteria upon contact have generated significant scientific attention. This interest was further stimulated by a report from Ivanova and co-workers, who reported that surface nanopillars resembling dragon fly surface architecture can efficiently kill medically relevant pathogens with great efficiency [61]. We have further added to the field by evaluating the effect of the nanostructure's outermost surface chemistry on antibacterial properties [62]. By applying a thin plasma polymer over layer, we were able to retain the original surface topography and to just fine tune the outermost surface chemistry. We found that hydrophilic plasma polymer coatings enhanced antimicrobial activity, while hydrophobic coatings reduced it [62]. Currently, our team is working with a commercial partner to transfer similar surface nanotopography on orthopaedic implants and bring it to market. As discussed above, QACs can be grafted to plasma polymer coatings to create contact killing surfaces $[19,20]$. Other potential alternatives for grafting on surfaces are antibacterial polymers and peptides, which have also attracted much attention in the last decade [26-28].

\section{Releasing Surfaces}

Surfaces and materials which release antibacterial compounds are the most commonly used ones due to their simplicity and efficacy to eliminate pathogens both on the surface of the device and in its vicinity.

\subsection{Silver Containing Coatings and Materials}

After being almost forgotten in the beginning of the era of antibiotics, silver came back to medicine in the second half of last century due to its antibacterial potency [63]. Materials incorporating silver are classified as releasing because of the way they work. Whether in the form of nanoparticles or continuous metallic layers, silver oxidizes when placed in a physiological medium. The oxide is then dissolved leading to the release of silver ions (Figure 3). These ions are the actual species which kill bacteria by a multifaceted mechanism of action, such as binding to the cell membrane causing lysis, blocking replication by binding to DNA, binding to enzymes and proteins and, in this way, interfering with 
bacterial metabolism. Silver is capable of killing both Gram-positive and Gram-negative pathogens. Due to such a multifaceted mechanism of action, it is also more difficult for bacteria to develop a resistance to silver compared to conventional antibiotics.

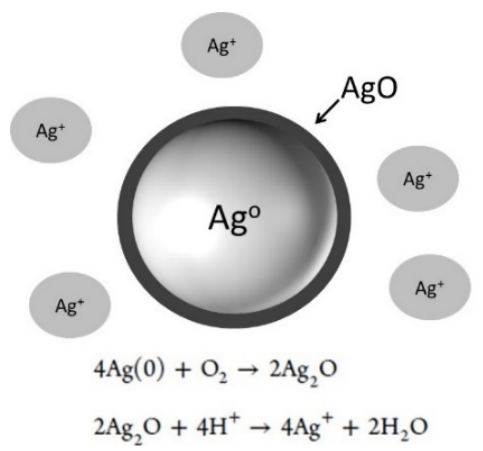

Figure 3. Mechanism for the dissolution of silver nanoparticles in an aqueous environment. The dissolved silver ions are the species killing bacteria.

Our team has done a significant body of work on antibacterial coatings containing silver nanoparticles [64-84]. In a paper published in Nano Letters in 2010, we were one of the first to report that mammalian cells can have greater tolerance to silver than bacteria [85]. These findings opened a therapeutic window for the safe application of silver on medical devices. To do that, we designed a platform which consisted of a $100 \mathrm{~nm}$ thick plasma polymer film rich in an amine group (Figure 4). This film was then loaded with silver ions by immersion in silver nitrate. The silver ions were then reduced to silver nanoparticles by immersion in sodium borohydride, which is a commonly used reduction agent. To control the rate of oxidation and dissolution of the silver nanoparticles and the subsequent release of silver ions, we applied a 'barrier' plasma polymer layer on top, which had precise thicknesses of 6,12 and $18 \mathrm{~nm}$. The thickness of the over layer was selected in a way to allow for sufficient silver ion release, and preserve the complete inhibition of bacterial attachment and biofilm formation. While there was some reduction in attachment of osteoblastic cells on the 'as prepared' silver nanoparticle loaded coating, we found that when the rate of silver ion release was reduced (even by the thinnest over layer) the cells grew and proliferated as if on a control without silver nanoparticles. This result pointed to the opportunity to design coatings for medical devices which are completely antibacterial but allow for normal tissue growth and integration. We also compared the efficacy of these coatings to commercial silver dressings (V.A.C. ${ }^{\circledR}$ GRANUFOAM ${ }^{\mathrm{TM}}$, Kinetic Concepts Inc., Texas, SA, US) containing a three micron thick silver layer and determined that the same antibacterial efficacy can be achieved with only a fraction of the amount of silver if nanoparticles are used [80].
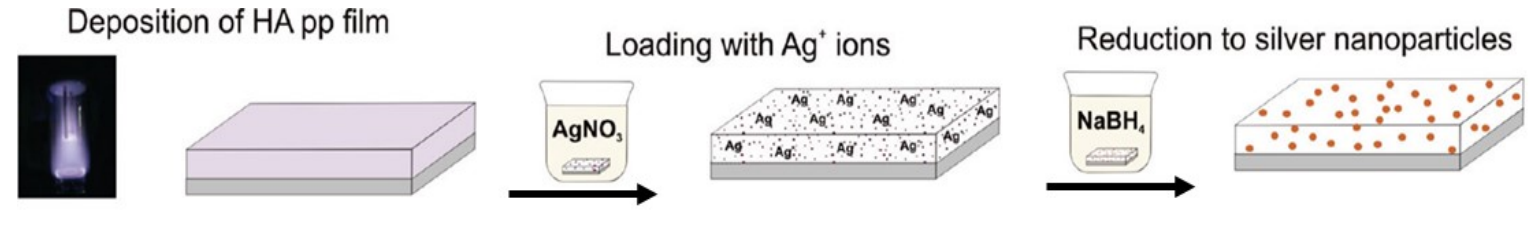

Figure 4. Schematic of the preparation of silver nanoparticles loaded films via first loading silver ions into an amine rich plasma polymer film deposited from the vapour of heptylamine (HA pp) followed by a reduction to silver nanoparticles.

We also prepared silver nanoparticles empowered antibacterial coatings and materials by first synthesizing the nanoparticles in solution and then attaching them to functional plasma polymer coatings (Figure 5) or incorporating them in hybrid materials. The synthetic protocols which we developed involve a range of reduction and capping agents (lipids, 2-mercaptosuccinic acid, citrate, polyvinyl-sulphonate, etc.), including a procedure that benefited from the properties of natural products, such as cacao extract $[64,71,73-78,83,86]$. These nanoparticles can be immobilised 
electrostatically or covalently to plasma polymer films containing appropriate surface functionalities (Figure 5) $[70,71,75,79,87]$. This method allows for easy control of the number of silver nanoparticles immobilised on the surface and can lead to coatings providing full protection against bacterial colonisation, favourable integration of mammalian cells and tissue, and the absence of adverse immune responses. Another way to use these silver nanoparticles is to incorporate them in the material itself, as we did with nanocapsules, nanoparticles and microneedle patches $[68,69,84]$. Recently, we discovered that ultra-small 1-2 nm silver (and gold) nanoparticles synthesised in an aqueous medium have a very high potency against a range of clinically relevant pathogens, but also reduce expression of pro-inflammatory cytokines from immune cells and help wounds to close [88-90]. We also combined silver nanoparticles and graphene oxide nanostructures and demonstrated a synergic bactericidal effect against Gram-positive and Gram-negative bacteria [81].

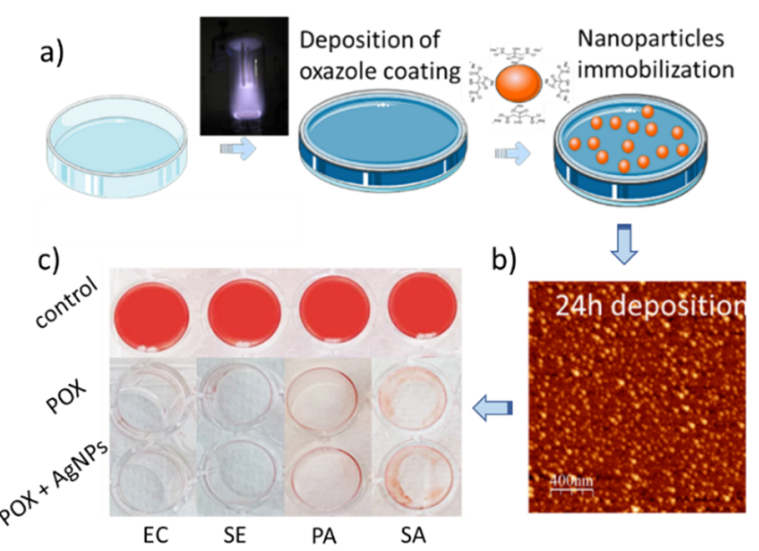

Figure 5. Preparation of silver nanoparticles decorated surfaces and their capacity to inhibit bacterial growth. (a) Substrates were first modified by a $20 \mathrm{~nm}$ thin layer of oxazoline based plasma polymer (POX). Silver nanoparticles (AgNPs) were synthesised in solution and covalently immobilized by immersion of the substrate for $24 \mathrm{~h}$. (b) An AFM (Atomic Force Microscopy) image visualising the silver nanoparticles immobilised to the substrate. (c) The POX and POX + AgNPs modified surfaces completely inhibit the growth of E. coli (EC), S. epidermidis (SE), P. aeruginosa (PA) and S. aureus (SA), while bacteria easily form biofilm on the control (red colour is staining with Safranin-O). Note that the POX coating is intrinsically non-biofouling (discussed above and shown in Figure 2), while the AgNPs release silver ions to eliminate bacteria in the vicinity of the substrate.

\subsection{Release of Conventional Antibiotics, Nitric Oxide and Antibacterial Polymers and Peptides}

Antibacterial agents can provide greater efficacy and lower systemic toxicity if released locally. We have developed coatings where levofloxacin was incorporated between two plasma polymer layers. By tuning the thickness of the outermost plasma polymer film, an efficient control of the rate of release could be achieved. Porous materials, such as nanoporous alumina and titania, could be used as reservoirs for loading antibacterials and biologicals [91-93]. Controlled release can be achieved by applying a plasma polymer on top of the structure to reduce the pore openings and, in this way, regulate the dissolution and release of the loaded drugs. Similar strategies could be applied for the release of antibacterial polymers and peptides, which attracted significant attention in the last decade [26-28]. Another interesting compound to be released from coatings or particulates is nitric oxide [23-25]. The molecule has the capacity to inhibit biofilm formation, however, it does not kill the bacteria and the antibacterial effect persists only until NO is released.

\section{Responsive Coatings}

Intelligent coatings and materials capable of selective release of antibacterial compounds only in the presence of bacteria are of substantial scientific and technological interest. Such materials are a major advance compared to the traditional release of antimicrobial agents, since toxicity to 
tissue is completely avoided if pathogens have not infiltrated the site of the device. Stimuli for responsive release could be $\mathrm{pH}$, temperature, reactive oxygen species (ROS) or enzymes, and toxins expressed by the bacteria [12] (Figure 6). We have created enzyme responsive nanoparticles and nanocapsules [29,30]. For example, in Reference [29], we synthesized hyaluronic acid nanocapsules containing polyhexanide. Pathogenic bacteria such as S. aureus express a number of toxins including an enzyme called hyaluronidase. We demonstrated that the nanocapsules would release their load only in the presence of this specific enzyme. The nanocapsules could also be loaded with fluorescent dyes. Thus, the nanomaterial not only kills the bacteria but also signals for their presence, in this manner informing the medical professional that attention is required.

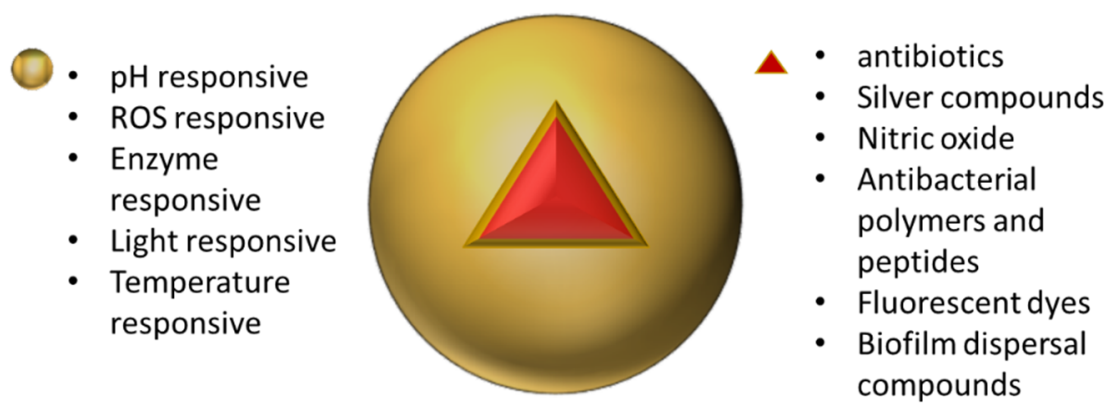

Figure 6. The core-shell architecture of a responsive (nano)material and the possible constituents of the core and shell.

\section{Future Outlook and Challenges}

The field of antibacterial coating technology has entered an exciting phase with new technologies continually emerging. The field will only continue to grow in the future since there is increasing recognition of the problem of infection by the medical community, leading to a strong technology pull from the biomedical device industry. As mentioned earlier in this article, and exemplified by orthopaedic devices, infections have become the main reason for device revision. After decades of development, devices such as knee and hip implants are quite sophisticated in terms of design and material selection, causing very few problems. However, infection rates have remained unchanged for decades. There is recognition by the community that a solution for this problem is urgently required. A device surface that is engineered to inhibit attachment of bacteria and biofilm formation could be an ideal solution. However, when such a surface is designed, specific care has to be taken not only regarding safety, but also the regulatory pathways that the new device has to go through. This is relevant for a range of medical devices, such as catheters, wound dressings, pacemakers, stents, tooth implants and stents, just to name a few. Antibacterial surfaces are needed not only in healthcare, but also in many other fields, good examples being the food and marine industries.

The author believes that intelligent materials and coatings that release antibacterial agents only when required and signal for the presence of pathogens will become a main area of development. Such materials would be applicable to many medical devices but particularly for items that are replaced on a relatively short-term basis, as for example wound dressings and catheters. The challenge is to demonstrate that in the absence of bacteria the material is capable of preventing release for substantially longer periods of time (six months or longer for dialysis catheters), but still responds quickly if stimuli are present. This leads to the challenge of selecting the specific stimuli. While temperature and $\mathrm{pH}$ are commonly used, it is difficult to design materials that are capable of responding sharply to very small changes in these two parameters in relevant ranges. Responsiveness to selective enzymes, such as lipases, which are expressed by pathogenic bacteria is an attractive option. However, since lipases are also expressed by some human cells, the material should be able to tolerate the natural variation in the level of these enzymes in the body when bacterial are not present. The same is valid for reactive oxygen species, which are released by immune cells to fight pathogens. If this fine balance is achieved, the immune response can be used to enhance the efficacy of the material by accelerating the release 
rate. There is a huge potential and market for such intelligent materials and our group is directing significant effort and resources to this area.

Funding: This research was funded by ARC (DP15104212, DP DP180101254), NHMRC (Fellowship APP1122825 and Project grant APP1032738), and the Alexander von Humboldt Foundation (Fellowship for Experienced Researchers).

Conflicts of Interest: The authors declare no conflict of interest.

\section{References}

1. Campoccia, D.; Montanaro, L.; Arciola, C.R. The significance of infection related to orthopedic devices and issues of antibiotic resistance. Biomaterials 2006, 27, 2331-2339. [CrossRef] [PubMed]

2. Vasilev, K.; Cook, J.; Griesser, H.J. Antibacterial surfaces for biomedical devices. Expert Rev. Med. Devices 2009, 6, 553-567. [CrossRef] [PubMed]

3. Bozic, K.; Kurtz, S.M.; Lau, E.; Ong, K.; Vail, T.P.; Rubash, H.E.; Berry, D.J. The epidemiology of revision total knee arthroplasty in the United States. J. Arthroplast. 2009, 24, e49. [CrossRef]

4. Kurtz, S.M.; Lau, E.; Watson, H.; Schmier, J.K.; Parvizi, J. Economic burden of periprosthetic joint infection in the United States. J. Arthroplast. 2012, 27, 61-65. [CrossRef] [PubMed]

5. Bleyer, A.J. Use of antimicrobial catheter lock solutions to prevent catheter-related bacteremia. Clin. J. Am. Soc. Nephrol. 2007, 2, 1073-1078. [CrossRef] [PubMed]

6. Johnson, D.W.; Dent, H.; Hawley, C.M.; McDonald, S.P.; Rosman, J.B.; Brown, F.G.; Bannister, K.M.; Wiggins, K.J. Associations of dialysis modality and infectious mortality in incident dialysis patients in Australia and New Zealand. Am. J. Kidney Dis. 2009, 53, 290-297. [CrossRef] [PubMed]

7. Dimick, J.B.; Pelz, R.K.; Consunji, R.; Swoboda, S.M.; Hendrix, C.W.; Lipsett, P.A. Increased resource use associated with catheter-related bloodstream infection in the surgical intensive care unit. Arch. Surg. 2001, 136, 229-234. [CrossRef] [PubMed]

8. Darouiche, R.O. Current concepts-Treatment of infections associated with surgical implants. N. Engl. J. Med. 2004, 350, 1422-1429. [CrossRef] [PubMed]

9. Kuehl, R.; Brunetto, P.S.; Woischnig, A.K.; Varisco, M.; Rajacic, Z.; Vosbeck, J.; Terracciano, L.; Fromm, K.M.; Khanna, N. Preventing implant-associated infections by silver coating. Antimicrob. Agents Chemother. 2016, 60, 2467-2475. [CrossRef] [PubMed]

10. Zimmerli, W.; Trampuz, A.; Ochsner, P.E. Current concepts: Prosthetic-joint infections. N. Engl. J. Med. 2004, 351, 1645-1654. [CrossRef]

11. Vasilev, K.; Griesser, S.S.; Griesser, H.J. Antibacterial surfaces and coatings produced by plasma techniques. Plasma Process. Polym. 2011, 8, 1010-1023. [CrossRef]

12. Cavallaro, A.; Taheri, S.; Vasilev, K. Responsive and "smart" antibacterial surfaces: Common approaches and new developments (Review). Biointerphases 2014, 9, 029005. [CrossRef] [PubMed]

13. Chernousova, S.; Epple, M. Silver as antibacterial agent: Ion, nanoparticle, and metal. Angew. Chem. Int. Ed. 2013, 52, 1636-1653. [CrossRef] [PubMed]

14. Cavallaro, A.A.; MacGregor-Ramiasa, M.N.; Vasilev, K. Antibiofouling properties of plasma-deposited Oxazoline-based thin films. ACS Appl. Mater. Interfaces 2016, 8, 6354-6362. [CrossRef] [PubMed]

15. Ramiasa, M.N.; Cavallaro, A.A.; Mierczynska, A.; Christo, S.N.; Gleadle, J.M.; Hayball, J.D.; Vasilev, K. Plasma polymerised polyoxazoline thin films for biomedical applications. Chem. Commun. 2015, 51, 4279-4282. [CrossRef] [PubMed]

16. Michl, T.D.; Coad, B.R.; Hüsler, A.; Valentin, J.D.P.; Vasilev, K.; Griesser, H.J. Effects of precursor and deposition conditions on prevention of bacterial biofilm growth on Chlorinated plasma polymers. Plasma Process. Polym. 2016, 13, 654-662. [CrossRef]

17. Michl, T.D.; Coad, B.R.; Doran, M.; Hüsler, A.; Valentin, J.D.P.; Vasilev, K.; Griesser, H.J. Plasma polymerization of 1,1,1-trichloroethane yields a coating with robust antibacterial surface properties. RSC Adv. 2014, 4, 27604-27606. [CrossRef]

18. Michl, T.D.; Barz, J.; Giles, C.; Haupt, M.; Henze, J.H.; Mayer, J.; Futrega, K.; Doran, M.R.; Oehr, C.; Vasilev, K.; et al. Plasma polymerization of TEMPO yields coatings containing stable Nitroxide radicals for controlling interactions with Prokaryotic and Eukaryotic Cells. ACS Appl. Nano Mater. 2018, 1, 6587-6595. [CrossRef] 
19. Cavallaro, A.; Mierczynska, A.; Barton, M.; Majewski, P.; Vasilev, K. Influence of immobilized quaternary ammonium group surface density on antimicrobial efficacy and cytotoxicity. Biofouling 2016, 32, 13-24. [CrossRef]

20. Cavallaro, A.; Majewski, P.; Barton, M.; Vasilev, K. Substrate independent approach for immobilisation of quaternary ammonium compounds to surfaces to reduce bio-burden. Mater. Sci. Forum 2014, 783, 1389-1395. [CrossRef]

21. Vasilev, K.; Poulter, N.; Martinek, P.; Griesser, H.J. Controlled release of levofloxacin sandwiched between two plasma polymerized layers on a solid carrier. ACS Appl. Mater. Interfaces 2011, 3, 4831-4836. [CrossRef] [PubMed]

22. Cavallaro, A.; Vasilev, K. Controlled and sustained release of pharmaceuticals via single step solvent-free encapsulation. Chem. Commun. 2015, 51, 1838-1841. [CrossRef] [PubMed]

23. Michl, T.D.; Coad, B.R.; Doran, M.; Osiecki, M.; Kafshgari, M.H.; Voelcker, N.H.; Hüsler, A.; Vasilev, K.; Griesser, H.J. Nitric oxide releasing plasma polymer coating with bacteriostatic properties and no cytotoxic side effects. Chem. Commun. 2015, 51, 7058-7060. [CrossRef] [PubMed]

24. Kafshgari, M.H.; Cavallaro, A.; Delalat, B.; Harding, F.J.; McInnes, S.J.P.; Mäkilä, E.; Salonen, J.; Vasilev, K.; Voelcker, N.H. Nitric oxide-releasing porous silicon nanoparticles. Nanoscale Res. Lett. 2014, 9, 333. [CrossRef] [PubMed]

25. Hasanzadeh Kafshgari, M.; Delalat, B.; Harding, F.J.; Cavallaro, A.; Mäkilä, E.; Salonen, J.; Vasilev, K.; Voelcker, N.H. Antibacterial properties of nitric oxide-releasing porous silicon nanoparticles. J. Mater. Chem. B 2016, 4, 2051-2058. [CrossRef]

26. Michl, T.D.; Locock, K.E.S.; Stevens, N.E.; Hayball, J.D.; Vasilev, K.; Postma, A.; Qu, Y.; Traven, A.; Haeussler, M.; Meagher, L.; et al. RAFT-derived antimicrobial polymethacrylates: Elucidating the impact of end-groups on activity and cytotoxicity. Polym. Chem. 2014, 5, 5813-5822. [CrossRef]

27. Locock, K.E.S.; Michl, T.D.; Valentin, J.D.P.; Vasilev, K.; Hayball, J.D.; Qu, Y.; Traven, A.; Griesser, H.J.; Meagher, L.; Haeussler, M. Guanylated polymethacrylates: A class of potent antimicrobial polymers with low hemolytic activity. Biomacromolecules 2013, 14, 4021-4031. [CrossRef] [PubMed]

28. Locock, K.E.S.; Michl, T.D.; Stevens, N.; Hayball, J.D.; Vasilev, K.; Postma, A.; Griesser, H.J.; Meagher, L.; Haeussler, M. Antimicrobial polymethacrylates synthesized as mimics of tryptophan-rich cationic peptides. ACS Macro Lett. 2014, 3, 319-323. [CrossRef]

29. Baier, G.; Cavallaro, A.; Vasilev, K.; Mailänder, V.; Musyanovych, A.; Landfester, K. Enzyme responsive hyaluronic acid nanocapsules containing polyhexanide and their exposure to bacteria to prevent infection. Biomacromolecules 2013, 14, 1103-1112. [CrossRef]

30. Baier, G.; Cavallaro, A.; Friedemann, K.; Müller, B.; Glasser, G.; Vasilev, K.; Landfester, K. Enzymatic degradation of poly(L-lactide) nanoparticles followed by the release of octenidine and their bactericidal effects. Nanomed. Nanotechnol. Biol. Med. 2014, 10, 131-139. [CrossRef]

31. Vasilev, K. Nanoengineered plasma polymer films for biomaterial applications. Plasma Chem. Plasma Process. 2014, 34, 545-558. [CrossRef]

32. Liu, X.; Shi, S.; Feng, Q.; Bachhuka, A.; He, W.; Huang, Q.; Zhang, R.; Yang, X.; Vasilev, K. Surface chemical gradient affects the differentiation of human adipose-derived stem cells via ERK1/2 signaling pathway. ACS Appl. Mater. Interfaces 2015, 7, 18473-18482. [CrossRef] [PubMed]

33. Mierczynska, A.; Michelmore, A.; Tripathi, A.; Goreham, R.V.; Sedev, R.; Vasilev, K. PH-tunable gradients of wettability and surface potential. Soft Matter 2012, 8, 8399-8404. [CrossRef]

34. Hazrati, H.D.; Whittle, J.D.; Vasilev, K. A mechanistic study of the plasma polymerization of ethanol. Plasma Process. Polym. 2014, 11, 149-157. [CrossRef]

35. Thierry, B.; Jasieniak, M.; De Smet, L.C.P.M.; Vasilev, K.; Griesser, H.J. Reactive epoxy-functionalized thin films by a pulsed plasma polymerization process. Langmuir 2008, 24, 10187-10195. [CrossRef]

36. MacGregor, M.N.; Michelmore, A.; Safizadeh Shirazi, H.; Whittle, J.; Vasilev, K. Secrets of plasma-deposited polyoxazoline functionality lie in the plasma phase. Chem. Mater. 2017, 29, 8047-8051. [CrossRef]

37. Michl, T.D.; Coad, B.R.; Hüsler, A.; Vasilev, K.; Griesser, H.J. Laboratory scale systems for the plasma treatment and coating of particles. Plasma Process. Polym. 2015, 12, 305-313. [CrossRef]

38. Michelmore, A.; Bryant, P.M.; Steele, D.A.; Vasilev, K.; Bradley, J.W.; Short, R.D. Role of positive ions in determining the deposition rate and film chemistry of continuous wave hexamethyl disiloxane plasmas. Langmuir 2011, 27, 11943-11950. [CrossRef] 
39. Coad, B.R.; Vasilev, K.; Diener, K.R.; Hayball, J.D.; Short, R.D.; Griesser, H.J. Immobilized streptavidin gradients as bioconjugation platforms. Langmuir 2012, 28, 2710-2717. [CrossRef]

40. Goreham, R.V.; Mierczynska, A.; Pierce, M.; Short, R.D.; Taheri, S.; Bachhuka, A.; Cavallaro, A.; Smith, L.E.; Vasilev, K. A substrate independent approach for generation of surface gradients. Thin Solid Films. 2013, 528, 106-110. [CrossRef]

41. Coad, B.R.; Scholz, T.; Vasilev, K.; Hayball, J.D.; Short, R.D.; Griesser, H.J. Functionality of proteins bound to plasma polymer surfaces. ACS Appl. Mater. Interfaces 2012, 4, 2455-2463. [CrossRef] [PubMed]

42. Vasilev, K.; Michelmore, A.; Martinek, P.; Chan, J.; Sah, V.; Griesser, H.J.; Short, R.D. Early stages of growth of plasma polymer coatings deposited from nitrogen- and oxygen-containing monomers. Plasma Process. Polym. 2010, 7, 824-835. [CrossRef]

43. Vasilev, K.; Michelmore, A.; Griesser, H.J.; Short, R.D. Substrate influence on the initial growth phase of plasma-deposited polymer films. Chem. Commun. 2009, 24, 3600-3602. [CrossRef] [PubMed]

44. Michelmore, A.; Martinek, P.; Sah, V.; Short, R.D.; Vasilev, K. Surface morphology in the early stages of plasma polymer film growth from amine-containing monomers. Plasma Process. Polym. 2011, 8, 367-372. [CrossRef]

45. Hernandez-Lopez, J.L.; Bauer, R.E.; Chang, W.S.; Glasser, G.; Grebel-Koehler, D.; Klapper, M.; Kreiter, M.; Leclaire, J.; Majoral, J.P.; Mittler, S.; et al. Functional polymers as nanoscopic building blocks. Mater. Sci. Eng. C 2003, 23, 267-274. [CrossRef]

46. McInnes, S.J.P.; Michl, T.D.; Delalat, B.; Al-Bataineh, S.A.; Coad, B.R.; Vasilev, K.; Griesser, H.J.; Voelcker, N.H. "Thunderstruck": Plasma-Polymer-Coated Porous Silicon Microparticles As a Controlled Drug Delivery System. ACS Appl. Mater. Interfaces 2016, 8, 4467-4476. [CrossRef] [PubMed]

47. Wahono, S.K.; Cavallaro, A.; Vasilev, K.; Mierczynska, A. Plasma polymer facilitated magnetic technology for removal of oils from contaminated waters. Environ. Pollut. 2018, 240, 725-732. [CrossRef]

48. Mierczynska-Vasilev, A.; Boyer, P.; Vasilev, K.; Smith, P.A. A novel technology for the rapid, selective, magnetic removal of pathogenesis-related proteins from wines. Food Chem. 2017, 232, 508-514. [CrossRef]

49. Ramiasa-MacGregor, M.; Mierczynska, A.; Sedev, R.; Vasilev, K. Tuning and predicting the wetting of nanoengineered material surface. Nanoscale 2016, 8, 4635-4642. [CrossRef]

50. Christo, S.N.; Bachhuka, A.; Diener, K.R.; Mierczynska, A.; Hayball, J.D.; Vasilev, K. The Role of Surface Nanotopography and Chemistry on Primary Neutrophil and Macrophage Cellular Responses. Adv. Healthc. Mater. 2016, 5, 956-965. [CrossRef]

51. Macgregor-Ramiasa, M.N.; Cavallaro, A.A.; Vasilev, K. Properties and reactivity of polyoxazoline plasma polymer films. J. Mater. Chem. B 2015, 3, 6327-6337. [CrossRef]

52. MacGregor, M.; Sinha, U.; Visalakshan, R.M.; Cavallaro, A.; Vasilev, K. Preserving the reactivity of coatings plasma deposited from oxazoline precursors-An in depth study. Plasma Process. Polym. 2019, 16, 1800130. [CrossRef]

53. Macgregor, M.; Vasilev, K. Perspective on plasma polymers for applied biomaterials nanoengineering and the recent rise of oxazolines. Materials 2019, 12, 191. [CrossRef] [PubMed]

54. Vasilev, K. Plasma derived oxazoline based coatings for advanced medical technologies. Galvanotechnik 2019, 110, 170-175.

55. Gonzalez Garcia, L.E.; Macgregor-Ramiasa, M.; Visalakshan, R.M.; Vasilev, K. Protein Interactions with Nanoengineered Polyoxazoline Surfaces Generated via Plasma Deposition. Langmuir 2017, 33, 7322-7331. [CrossRef] [PubMed]

56. Chen, Z.; Visalakshan, R.M.; Guo, J.; Wei, F.; Zhang, L.; Chen, L.; Lin, Z.; Vasilev, K.; Xiao, Y. Plasma deposited poly-oxazoline nanotextured surfaces dictate osteoimmunomodulation towards ameliorative osteogenesis. Acta Biomater. 2019, 96, 568-581. [CrossRef] [PubMed]

57. Macgregor-Ramiasa, M.; McNicholas, K.; Ostrikov, K.; Li, J.; Michael, M.; Gleadle, J.M.; Vasilev, K. A platform for selective immuno-capture of cancer cells from urine. Biosens. Bioelectron. 2017, 96, 373-380. [CrossRef]

58. Visalakshan, R.M.; MacGregor, M.N.; Cavallaro, A.A.; Sasidharan, S.; Bachhuka, A.; Mierczynska-Vasilev, A.M.; Hayball, J.D.; Vasilev, K. Creating Nano-engineered Biomaterials with Well-Defined Surface Descriptors. ACS Appl. Nano Mater. 2018, 1, 2796-2807. [CrossRef]

59. Visalakshan, R.M.; MacGregor, M.N.; Sasidharan, S.; Ghazaryan, A.; Mierczynska-Vasilev, A.M.; Morsbach, S.; Mailänder, V.; Landfester, K.; Hayball, J.D.; Vasilev, K. Biomaterial Surface Hydrophobicity-Mediated Serum Protein Adsorption and Immune Responses. ACS Appl. Mater. Interfaces 2019. [CrossRef] 
60. Al-Bataineh, S.A.; Cavallaro, A.A.; Michelmore, A.; Macgregor, M.N.; Whittle, J.D.; Vasilev, K. Deposition of 2-oxazoline-based plasma polymer coatings using atmospheric pressure helium plasma jet. Plasma Process. Polym. 2019. [CrossRef]

61. Ivanova, E.P.; Hasan, J.; Webb, H.K.; Gervinskas, G.; Juodkazis, S.; Truong, V.K.; Wu, A.H.; Lamb, R.N.; Baulin, V.A.; Watson, G.S.; et al. Bactericidal activity of black silicon. Nat. Commun. 2013, 4, 2838. [CrossRef]

62. Ostrikov, K.; MacGregor-Ramiasa, M.; Cavallaro, A.; Vasilev, K. Bactericidal effects of plasma-modified surface chemistry of silicon nanograss. J. Phys. D Appl. Phys. 2016, 49, 304001. [CrossRef]

63. Alexander, J.W. History of the medical use of silver. Surg. Infect. 2009, 10, 289-292. [CrossRef]

64. Vasilev, K.; Sah, V.R.; Goreham, R.V.; Ndi, C.; Short, R.D.; Griesser, H.J. Antibacterial surfaces by adsorptive binding of polyvinyl-sulphonate-stabilized silver nanoparticles. Nanotechnology 2010, 21, 215102. [CrossRef] [PubMed]

65. Ploux, L.; Mateescu, M.; Anselme, K.; Vasilev, K. Antibacterial properties of silver-loaded plasma polymer coatings. J. Nanomater. 2012, 2012, 6. [CrossRef]

66. Lombi, E.; Donner, E.; Taheri, S.; Tavakkoli, E.; Jämting, Å.K.; McClure, S.; Naidu, R.; Miller, B.W.; Scheckel, K.G.; Vasilev, K. Transformation of four silver/silver chloride nanoparticles during anaerobic treatment of wastewater and post-processing of sewage sludge. Environ. Pollut. 2013, 176, 193-197. [CrossRef] [PubMed]

67. Poulter, N.; Vasilev, K.; Griesser, S.S.; Griesser, H.J. Silver containing biomaterials. In Biomaterials Associated Infection: Immunological Aspects and Antimicrobial Strategies; Springer: Berlin/Heidelberg, Germany, 2013; pp. 355-378.

68. Taheri, S.; Baier, G.; Majewski, P.; Barton, M.; Förch, R.; Landfester, K.; Vasilev, K. Synthesis and surface immobilization of antibacterial hybrid silver-poly(L-lactide) nanoparticles. Nanotechnology 2014, 25, 305102. [CrossRef] [PubMed]

69. Taheri, S.; Baier, G.; Majewski, P.; Barton, M.; Förch, R.; Landfester, K.; Vasilev, K. Synthesis and antibacterial properties of a hybrid of silver-potato starch nanocapsules by miniemulsion/polyaddition polymerization. J. Mater. Chem. B 2014, 2, 1838-1845. [CrossRef]

70. Taheri, S.; Cavallaro, A.; Barton, M.; Whittle, J.D.; Majewski, P.; Smith, L.E.; Vasilev, K. Antibacterial efficacy and cytotoxicity of silver-nanoparticle-based coatings facilitated by a plasma deposited polymer interlayer. Plasma Med. 2014, 4, 101-115. [CrossRef]

71. Taheri, S.; Cavallaro, A.; Christo, S.N.; Smith, L.E.; Majewski, P.; Barton, M.; Hayball, J.D.; Vasilev, K. Substrate independent silver nanoparticle based antibacterial coatings. Biomaterials 2014, 35, 4601-4609. [CrossRef]

72. Brunetti, G.; Donner, E.; Laera, G.; Sekine, R.; Scheckel, K.G.; Khaksar, M.; Vasilev, K.; De Mastro, G.; Lombi, E. Fate of zinc and silver engineered nanoparticles in sewerage networks. Water Res. 2015, 77, 72-84. [CrossRef] [PubMed]

73. Khaksar, M.; Jolley, D.F.; Sekine, R.; Vasilev, K.; Johannessen, B.; Donner, E.; Lombi, E. In situ chemical transformations of silver nanoparticles along the water-sediment continuum. Environ. Sci. Technol. 2015, 49, 318-325. [CrossRef] [PubMed]

74. Sekine, R.; Khurana, K.; Vasilev, K.; Lombi, E.; Donner, E. Quantifying the adsorption of ionic silver and functionalized nanoparticles during ecotoxicity testing: Test container effects and recommendations. Nanotoxicology 2015, 9, 1005-1012. [CrossRef] [PubMed]

75. Taheri, S.; Cavallaro, A.; Christo, S.N.; Majewski, P.; Barton, M.; Hayball, J.D.; Vasilev, K. Antibacterial Plasma Polymer Films Conjugated with Phospholipid Encapsulated Silver Nanoparticles. ACS Biomater. Sci. Eng. 2015, 1, 1278-1286. [CrossRef]

76. Taheri, S.; Vasilev, K.; Majewski, P. Silver nanoparticles: Synthesis, antimicrobial coatings, and applications for medical devices. Recent Pat. Mater. Sci. 2015, 8, 166-175. [CrossRef]

77. Alhmoud, H.; Delalat, B.; Ceto, X.; Elnathan, R.; Cavallaro, A.; Vasilev, K.; Voelcker, N.H. Antibacterial properties of silver dendrite decorated silicon nanowires. RSC Adv. 2016, 6, 65976-65987. [CrossRef]

78. Chowdhury, N.R.; MacGregor-Ramiasa, M.; Zilm, P.; Majewski, P.; Vasilev, K. 'Chocolate' silver nanoparticles: Synthesis, antibacterial activity and cytotoxicity. J. Colloid Interface Sci. 2016, 482, 151-158. [CrossRef]

79. He, W.; Elkhooly, T.A.; Liu, X.; Cavallaro, A.; Taheri, S.; Vasilev, K.; Feng, Q. Silver nanoparticle based coatings enhance adipogenesis compared to osteogenesis in human mesenchymal stem cells through oxidative stress. J. Mater. Chem. B 2016, 4, 1466-1479. [CrossRef] 
80. Ostrikov, K.; Macgregor-Ramiasa, M.N.; Cavallaro, A.A.; Jacob, M.; Vasilev, K. A comparative assessment of nanoparticulate and metallic silver coated dressings. Recent Pat. Mater. Sci. 2016, 9, 50-57. [CrossRef]

81. Prasad, K.; Lekshmi, G.S.; Ostrikov, K.; Lussini, V.; Blinco, J.; Mohandas, M.; Vasilev, K.; Bottle, S.; Bazaka, K.; Ostrikov, K. Synergic bactericidal effects of reduced graphene oxide and silver nanoparticles against Gram-positive and Gram-negative bacteria. Sci. Rep. 2017, 7, 1591. [CrossRef]

82. Schmidt-Braekling, T.; Streitbuerger, A.; Gosheger, G.; Boettner, F.; Nottrott, M.; Ahrens, H.; Dieckmann, R.; Guder, W.; Andreou, D.; Hauschild, G. Silver-coated megaprostheses: Review of the literature. Eur. J. Orthop. Surg. Traumatol. 2017, 27, 483-489. [CrossRef] [PubMed]

83. Roy Chowdhury, N.; Hopp, I.; Zilm, P.; Murray, P.; Vasilev, K. Silver nanoparticle modified surfaces induce differentiation of mouse kidney-derived stem cells. RSC Adv. 2018, 8, 20334-20340. [CrossRef]

84. González García, L.E.; MacGregor, M.N.; Visalakshan, R.M.; Ninan, N.; Cavallaro, A.A.; Trinidad, A.D.; Zhao, Y.; Hayball, A.J.D.; Vasilev, K. Self-sterilizing antibacterial silver-loaded microneedles. Chem. Commun. 2019, 55, 171-174. [CrossRef] [PubMed]

85. Vasilev, K.; Sah, V.; Anselme, K.; Ndi, C.; Mateescu, M.; Dollmann, B.; Martinek, P.; Ys, H.; Ploux, L.; Griesser, H.J. Tunable antibacterial coatings that support mammalian cell growth. Nano Lett. 2010, 10, 202-207. [CrossRef] [PubMed]

86. Chowdhury, N.R.; Cowin, A.J.; Zilm, P.; Vasilev, K. “Chocolate” gold nanoparticles-One pot synthesis and biocompatibility. Nanomaterials 2018, 8, 496. [CrossRef]

87. Taheri, S.; Ruiz, J.C.; Michelmore, A.; Macgregor, M.; Förch, R.; Majewski, P.; Vasilev, K. Binding of Nanoparticles to Aminated Plasma Polymer Surfaces is Controlled by Primary Amine Density and Solution pH. J. Phys. Chem. C 2018, 122, 14986-14995. [CrossRef]

88. Biswas, B.; Warr, L.N.; Hilder, E.F.; Goswami, N.; Rahman, M.M.; Churchman, J.G.; Vasilev, K.; Pan, G.; Naidu, R. Biocompatible functionalisation of nanoclays for improved environmental remediation. Chem. Soc. Rev. 2019, 48, 3740-3770. [CrossRef]

89. Goswami, N.; Bright, R.; Visalakshan, R.M.; Biswas, B.; Zilm, P.; Vasilev, K. Core-in-cage structure regulated properties of ultra-small gold nanoparticles. Nanoscale Adv. 2019, 1, 2356-2364. [CrossRef]

90. Ravindran Girija, A.; Balasubramanian, S.; Bright, R.; Cowin, A.J.; Goswami, N.; Vasilev, K. Ultrasmall Gold Nanocluster Based Antibacterial Nanoaggregates for Infectious Wound Healing. ChemNanoMat 2019. [CrossRef]

91. Simovic, S.; Losic, D.; Vasilev, K. Controlled drug release from porous materials by plasma polymer deposition. Chem. Commun. 2010, 46, 1317-1319. [CrossRef]

92. Simovic, S.; Diener, K.R.; Bachhuka, A.; Kant, K.; Losic, D.; Hayball, J.D.; Brownc, M.P.; Vasilev, K. Controlled release and bioactivity of the monoclonal antibody rituximab from a porous matrix: A potential in situ therapeutic device. Mater. Lett. 2014, 130, 210-214. [CrossRef]

93. Müller, S.; Cavallaro, A.; Vasilev, K.; Voelcker, N.H.; Schönherr, H. Temperature-Controlled Antimicrobial Release from Poly(diethylene glycol methylether methacrylate)-Functionalized Bottleneck-Structured Porous Silicon for the Inhibition of Bacterial Growth. Macromol. Chem. Phys. 2016, 217, 2243-2251. [CrossRef]

(C) 2019 by the author. Licensee MDPI, Basel, Switzerland. This article is an open access article distributed under the terms and conditions of the Creative Commons Attribution (CC BY) license (http://creativecommons.org/licenses/by/4.0/). 